J. Perinat. Med.

2 (1974) 61

\section{The necessity for thermal prophylaxis in the neonate}

\author{
H. Schachinger, L. Ballowitz, H.-D. Frank \\ Department of Pediatrics of the Free University Berlin - Kaiserin Auguste \\ Victoria Haus
}

Received January 3, 1973. Accepted May 24, 1973.
The admission of hypothermic newborn and especially premature infants continues to be an everyday problem in pediatric intensive care units $[21,22,33,34]$. The principal reason is the lack of consideration for the mechanisms and dangers of heat loss for newborns immediately after birth.

\subsection{The causes of heat loss}

The mechanisms of heat loss are determined by the special factors of body proportions and by environmental factors. The loss of heat to the environment occurs by conduction, convection, radiation and evaporation. The basic physical laws include the following relevant factors: air temperature (the temperature difference between body and environment), air humidity (the vapor pressure of the skin is greater than that of the air), air speed, wall temperature, the radius of the body, and the ratio of surface to volume of this body.

The surface/volume ratio is considerably greater in the premature and newborn than in the adult (Tab. I). The resulting increase in heat loss is enhanced by the lower insulation of the thin subcutaneous layer of fat. The proportion of the body surface exposed to the environment is $50-80 \%$ of the anatomical surface depending on the posture [24]. For intubated patients an additional consideration is the fact that $10 \%$ of the total heat loss occurs through the internal surface of the respiratory system [24].

\section{Curriculum vitae}

Harald Schachinger was born in Berlin in 1939 and received bis secondary education in Freiburg and Erlangen. He attended the medical scbools in Vienna and Erlangen where be graduated in 1966. After bis Internsbip in West Berlin be was a trainee in the Department of Patbologi at the University of Erlangen-Nürnberg and in the Department of Physiology' at the Medical School in Hannover. Since 1970 be bas been a pediatric resident at the Children's Hospital of the Free University of Berlin. His areas of interest include pediatric intensive care and neonatology.

Tab. I. The relation of surface/volume ratio to body weight [41].

\begin{tabular}{lrc}
\hline Organism & $\begin{array}{c}\text { Surface/ } \\
\text { Volume Ratio } \\
\left(\mathrm{cm}^{-1}\right)\end{array}$ \\
\hline Child & $20 \mathrm{~kg}$ & 0.2 \\
Term Newborn & $3 \mathrm{~kg}$ & 0.6 \\
Premature & $1.5 \mathrm{~kg}$ & 0.8 \\
\hline
\end{tabular}

\subsection{Maintenance of body temperature}

The maintenance of body temperature is regulated in the human, a homoiothermic animal, via neural and humoral pathways with the following regulators:

1. internal organs and skeletal muscles: for production of heat, 
2. cutaneous vasculature: for the regulation of convective heat loss,

3. sweat glands: for the regulation of heat loss by evaporation.

While the newborn has fully functioning vascular reactions $[3,6,14]$ and good sweat gland secretions $[26,45]$ muscular shivering, as in the adult, is seen only under special circumstances, e. g. by the action of drugs such as adrenolytics (beta-receptor blockers) [9]. The absence of shivering was formerly interpreted as immaturity of temperature regulation. However, the heat production of the newborn is maintained essentially by metabolic processes in the brown fat in conjunction with the sympathetic nervous system $[3,23,28,29,30]$. The brown fat is located predominately between the scapulae and the neck, lesser amounts are to be found behind the 'sternum and along the vertebral column. It amounts to about 2-6\% of the body weight, it is particularly rich in mitochondria and is well perfused with blood [13, 46]. The white fat contributes also to reproduction of heat $[38,52]$. Because of the heat produced by lipolysis rather than by shivering, the term "non-shivering thermogenesis of the neonate" has been introduced. This is considerably more effective because the movement of shivering adds to the heat loss by convection. In summary, the newborn has a capable mechanism of temperature regulation.

\subsection{Neutral temperature}

When caring for neonates it should be considered that for them the neutral temperature or "temperature of comfort" (temperature of quiet sleep) at a relative humidity of $50 \%$ of the ambient air is between $32^{\circ}$ and $34^{\circ} \mathrm{C}$. This is defined as the temperature at which the basal metabolism, particularly oxygen consumption, is at its lowest [8]. According to investigations of Hey and Katz [27] in which birth weight and age were taken into consideration, the neutral temperature of prematures is in excess of $34^{\circ} \mathrm{C}$.

\subsection{The hypothermic neonate}

The response of the neonate to a cool environment has been investigated by numerous authors during the last 20 years $[1,2,5,20,25,40,42,48]$. Many changes of metabolic function occur as a consequence of exposurio to cold. Immediately after a birth both term and premature infants are able to decrease cutaneous circulation in order to resist the convective heat loss more effectively [5]. However, this vasoconstrictive protection is not sufficient to counteract the entire heat loss. The increase in the metabolic rate necessary for the production of heat reaches values which cannot be achieved by the adult organism (Tab. II).

Tab. II. Comparison of increase in the metabolic rate between term infants and prematures on the first day of life and adults as a response to cooling [5].

\begin{tabular}{lcc}
\hline $\begin{array}{c}\text { Basal Metabolism } \\
(\mathrm{kcal} / \mathrm{kg} / \mathrm{h})\end{array}$ & $\begin{array}{c}\text { Metabolism at } \\
\text { environmental } \\
\text { temperature of } \\
23^{\circ} \mathrm{C} \\
(\mathrm{kcal} / \mathrm{kg} / \mathrm{h})\end{array}$ \\
\hline Term Newborn & 1.43 & 2.96 \\
Premature & 1.44 & 2.04 \\
Adult & 1.00 & up to 1.25 \\
\hline
\end{tabular}

In a cold environment oxygen consumption can increase up to $100 \%$ and more if central temperature regulation and circulation are intact $[2,17,25,48]$. Critical for the regulatory mechanism is the temperature gradient between skin and environment and only secondarily the rectal temperature [2]. For the neonate with respiratory difficulties the "increased oxygen consumption amounts to an increased risk. The increasing tissue hypoxia causes an increased anaerobic glycolysis which in turn enhances acidosis because of the increased production of lactate.

In addition, hypothermia causes an increase in free fatty acids as a consequence of an increase in catecholamines [42, 45, 47, 48]. Varying responses of blood sugar levels have been reported. Some authors report a decrease of blood sugar [42, 47] while others have reported an increase or no significant change $[17,40]$. In a cold environment newborns at the age of a few hours have an increase in thyrotropin [18] as compared with 1 -3 day old infants in a similar environment 
Tab. III. A schematic outline of the principal responses to cold exposure.

Ambient Temperature
Skin Temperature
Skin Circulation
Rectal Temperature
pH
Heat Production
$\mathrm{O}_{2}$-Consumption
Noradrenaline
Free Fatty Acids
Lactate

[17]. The most important changes have been summarized in Tab. III.

The increasing acidosis (leading to a decrease of the albumin-bilirubin binding capacity) as well as the increase in free fatty acids (causing a competitive displacement of bilirubin from the albumin-bilirubin complex) increase the capacity of bilirubin to diffuse into the tissue. Thus the risk for kernicterus is increased [47].

As a consequence, exogenous cooling can eventually lead to an exhaustion of energy sources and a cessation of heat production. This deterioration in the general condition of a neonate is particularly dangerous if it occurs in the presence of perinatal shock. The increasing acidosis leads to disturbances of microcirculation and thus to a consumption coagulopathy. The consequence are hemorrhages and possibly this is one of the pathogenetic factors of pulmonary hyaline membranes [4]. The development of such membranes will interfere with oxygen uptake.

The mortality of hypothermic neonates in contrast to normothermic neonates is high $[10,15,44]$. With every abnormal birth the primary poor general condition caused by perinatal shock might deteriorate by exogenous - often iatrogenic - cooling to an extent that all help is futile. Because infants have a delayed vascular reaction and a decreased heat production after a pathologic birth [7] they are at particular risk of becoming hypothermic. It is these high- risk infants who are often transferred from obstetrical departments to pediatric institutions.

\subsection{The importance of immediate care in the delivery room}

Our own observations indicate that during the last few years not all the necessary practical consequences have been drawn in spite of the increase in knowledge about temperature regulation. In the first half of 1971, 255 newborn infants in the first 24 hours of life were admitted to the Children's Hospital of the Free University of Berlin. The average admission temperature was $35.5^{\circ} \mathrm{C}( \pm 1.03)$. The correlation with birth weights shows clearly that infants with a low birth weight had particularly low body temperatures (Tab. IV). Only those infants with birth weights over $3 \mathrm{~kg}$ had an admission temperature of over $36^{\circ} \mathrm{C}$. The 32 infants who died $(12.9 \%)$ had a mean admission temperature of $34.1^{\circ} \mathrm{C}$ $( \pm 1.28)$. It is noteworthy that the proximity of the referring hospital is not necessarily a guarantee for high admission temperatures (Tab. V). Infants transferred immediately post partum as a rule were colder than those a few hours older (Tab. VI). If these results are compared with those seen in our institution 14 years earlier, it is seen that then $30.7 \%$ of newborns under $2500 \mathrm{~g}$ had an admission temperature of less than $35^{\circ} \mathrm{C}$ while in the current series they accounted for $32.8 \%$.

The immediate care in the delivery room appears to be of decisive importance for the prevention of heat loss. According to our data the magnitude of the heat loss is not dependent on the season or the distance to the referring hospital and has not improved in spite of modern means of transportation. Because even at a normal delivery the rectal temperature falls within 5 minutes by $0.5^{\circ} \mathrm{C}$ and the skin temperature by $2-5^{\circ} \mathrm{C}[11,32,9,49]$ the following simple methods of preventing heat loss should be considered: Incorrectly positioned heat lamps are frequently found [35]; they are often positioned so that during resuscitation the head, neck, and shoulders of the midwife or physician are between the lamp and the infant. Often these lamps are turned on too late, i. e. only after the infant has been born. It is over- 
Tab. IV. Temperature of neonates of varying birth weight classes on admission to the Children's Hospital.

\begin{tabular}{|c|c|c|c|c|}
\hline $\begin{array}{l}\text { Birth weight } \\
\text { (g) }\end{array}$ & $\begin{array}{l}\text { Number of patients } \\
\text { (n) }\end{array}$ & $\%$ & $\begin{array}{l}\text { Admission temperature } \\
\left({ }^{\circ} \mathrm{C}\right)\end{array}$ & $\begin{array}{c}\text { died } \\
(n)\end{array}$ \\
\hline$<1000$ & 11 & 4.3 & $33.2( \pm 1.19)$ & 9 \\
\hline $1001-1500$ & 10 & 3.9 & $34.3( \pm 1.36)$ & 5 \\
\hline $1501-2000$ & 41 & 16.1 & $35.2( \pm 0.80)$ & 9. \\
\hline $2001-2500$ & 84 & 32.9 & $35.6( \pm 0.69)$ & 5 \\
\hline $2501-3000$ & 29 & 11.4 & $35.8( \pm 0.76)$ & 2 \\
\hline $3001-3500$ & 40 & 15.7 & $36.0( \pm 0.64)$ & 1 \\
\hline $3501-4000$ & 27 & 10.6 & $36.3( \pm 0.76)$ & 1 \\
\hline$>4000$ & 13 & 5.1 & $36.0( \pm 0.62)$ & \\
\hline mean & $\Sigma \mathrm{n}$ & & mean & $\Sigma_{\mathrm{n}}$ \\
\hline 2547 & 255 & 100 & $35.5( \pm 1.03)$ & 32 \\
\hline
\end{tabular}

Tab. V. Distance of referring hospital to the Children's Hospital and admission temperatures.

\begin{tabular}{lllll}
\hline Distance from referring hospital $(\mathrm{km})$ & 1 & 9 & 16 & 22 \\
\hline Number of patients $(\mathrm{n})$ & 96 & 64 & 55 & 16 \\
\hline$\%$ & 37.6 & 25.1 & 21.6 & 6.3 \\
\hline Admission temperature $\left({ }^{\circ} \mathrm{C}\right)$ & 35.4 & 35.6 & 35.6 & 36.1 \\
\hline $\mathrm{s}$ & 0.97 & 1.05 & 1.03 & 0.84 \\
\hline
\end{tabular}

Tab. VI. Admission temperatures and age at admission.

\begin{tabular}{llllll}
\hline Age at admission $(\mathrm{h})$ & under 1 & $1.1-2$ & $2.1-4$ & $4.1-8$ & $8.1-24$ \\
\hline Number of patients & 86 & 96 & 34 & 15 & 24 \\
\hline$\%$ & 33.7 & 37.6 & 13.4 & 5.9 & 35.8 \\
\hline Admission temperature & 35.2 & 35.5 & 35.7 & 0.86 & 36.3 \\
\hline $\mathrm{s}$ & 1.15 & 0.92 & 0.85 & 0.52 \\
\hline
\end{tabular}

looked that the towels on which the newborn infant is placed as well as the infant are moist and thus contribute to an increased heat loss. Often the prevention of heat loss is forgotten during hastily carried out resuscitation with endotracheal suctioning, intubation, and injection into umbilical vessels. It must be stressed that all these measures can be carried out if the infants are covered with preheated towels. Resuscitation becomes ineffective if the neonate because of heat loss is put into a state of increased metabolic demand and oxygen consumption and with the consequent tissue hypoxia contributing to the further deterioration of the infant's condition. Many first aid measures including artificial ventilation can be carried out in heated cribs and incubators which unfortunately have not yet found sufficient acceptance in delivery rooms. With appropriate modifications these incubators can be utilized for use in both resuscitation as well as transportation. Good temperature protection is afforded by the resuscitation unit described by SEMM and KRESS [43], now commercially available, in which the infant is accessible from all sides under a warm air hood in a heat shell. 


\subsection{The hyperthermic neonate}

Excessive warming of the neonate must also be avoided. In addition to vasal dilatation $[6,14]$ sweat secretion occurs with rectal temperatures of over $37.2^{\circ} \mathrm{C}$ [45]. With environmental temperatures between $36^{\circ}$ and $38^{\circ} \mathrm{C}$ as well as with a minimal increase of the body temperature oxygen consumption can rise to $10 \mathrm{ml} / \mathrm{kg}$ per minute (normal $4.6-4.8 \mathrm{ml} / \mathrm{kg}$ per minute) [2]. With increased environmental temperatures there is an increased incidence of apnoic attacks $[12,27]$ particularly during the process of warming [39]. Hyperthermia as well as hypothermia in prematures, dysmatures, as well as infants with poor Apgar-scores following a difficult delivery lead to an exhaustion of energy sources because of the increased metabolic rate, thus further deteriorating the general condition.

\section{Summary}

Environmental factors and body proportions are responsible for the heat loss of neonates immediately after birth. Besides the thin subcutaneous layer of fat especially in prematures and dysmatures, there is a surface/volume ratio of 3 to 4 times greater than that of adults (Tab. I).

Because of its functioning temperature regulation, the newborn is capable of controlling heat loss within certain limits. Term and premature infants are capable of vascular responses and of good sweat secretion. Heat production is maintained through the metabolic processes in the white and especially in the brown fat. The absence of shivering has led to the term "non-shivering thermogenesis of the neonate". The neutral temperature, i. e. that enviromental temperature at which the basal metabolism is lowest, is at $50 \%$ relative humidity between $32^{\circ}$ and $34^{\circ} \mathrm{C}$ for term infants, for prematures depending upon birth weight and age it may be above $34^{\circ} \mathrm{C}$. Hyperthermia in a neonate leads to vasodilatation and sweat secretion. With environmental temperatures of $36^{\circ}$ to $38^{\circ} \mathrm{C}$ oxygen consumption is doubled. Particular attention has to be paid to the frequent apnoic attacks, especially during the warming phase.

Exposure of the neonate to cold results in vasoconstriction which as a rule is not sufficient to counteract the entire heat loss. For instance, an environmental temperature of $23^{\circ} \mathrm{C}$ will result in metabolism (Tab. II) and oxygen consumption of over $100 \%$. Furthermore, there is an increase of catecholamines, free fatty acids and lactate with a resulting metabolic acidosis (Tab. III). Blood sugar values can be increased or decreased during the first few hours of

\section{Hypothermia: a therapeutic measure?}

Miller [36] and Westin [50] have suggested a therapeutic hypothermia in order to decrease the increased oxygen consumption of infants at risk. Especially in animal experiments this mode of resuscitation appears to be successful in the presence of severe asphyxia $[16,36,50,51]$. It is important to block the attempts of the central regulatory control mechanism to counteract the heat loss when hypothermia is used. Thus in animal experiments this effect is said to be achieved by rapid chilling while in asphyxiated neonates the counter-regulation might be primarily inhibited by hypoxia and hypercapnia $[36,37]$. There are very few clinical experiences, so that hypothermia currently cannot be recommended. As long as newborn infants are being resuscitated in the traditional way the initial care of the neonate must include sufficient and continuous protection from heat loss.

life. During the cold stress an increased level in thyrotropin is found. The capacity of bilirubin to diffuse into the tissue is increased in hypothermic neonates with a consequent higher risk of kernicterus. Infants from high-risk deliveries have a delayed onset of vascular response and a decreased heat production; they are particularly prone to rapid cooling.

The mean temperature at admission of 255 newborn infants admitted to the Children's Hospital of the Free University of Berlin in the first halt of 1971 was $35.5^{\circ} \mathrm{C}$ (Tab. IV). The temperature depended on the birth weight and age after birth. The admission temperature was independent from the distance to the referring hospital (Tab. V) and from the season. It must be assumed that most of the heat loss occurs immediately after birth (Tab. VI). It must be emphasized that warming devices are turned on sufficiently early and positioned correctly. Wet towels must be removed from the area where the infant is received because of the increased evaporative heat loss. The infants should be covered at all times. In order to insure a continuous protection from heat loss between birth and admission to the nursery, delivery rooms should be equipped with more warming cots and incubators within which it should be possible to resuscitate an infant.

Because of the lack of experience with controlled hypothermia in newborns as a means of lowering oxygen consumption, adequate protection from heat loss during the immediate care of neonates is still imperative.

Keywords: Body temperature regulation, environment (neonatal), infant care. 


\section{Zusammenfassung}

Die Notwendigkeit der Wärmevorsorge bei Neugeborenen

Für die Auskühlung Neugeborener unmittelbar post partum können die veränderten Umgebungsfaktoren und der Körperbau verantwortlich gemacht werden. Neben der dünnen subkutanen Fettschicht besonders der Früh- und Mangelgeborenen besteht gegenüber Erwachsenen ein 3-4mal größeres Oberflächen-Volumen-Verhältnis (Tab. I). Das Neugeborene vermag durch eine leistungsfähige Temperaturregulierung den ständigen Wärmeabstrom in gewissen Grenzen zu halten. Reif- und Frühgeborene besitzen voll funktionstüchtige Gefäßreaktionen und eine gute Schweißdrüsensekretion. Die Wärmeproduktion wird durch Stoffwechselprozesse im weißen und besonders im braunen Fettgewebe aufrechterhalten. Wegen des Fehlens des Muskelzitterns wird von zitterfreier Thermogenese des Neugeborenen gesprochen.

Die Neutraltemperatur, jene Umgebungstemperatur, bei der der Basisstoffwechsel am geringsten ist, liegt bei Reifgeborenen bei $50 \%$ Luftfeuchtigkeit zwischen $32^{\circ}$ und $34^{\circ} \mathrm{C}$, bei Frühgeborenen je nach Geburtsgewicht und Lebensalter sogar über $34^{\circ} \mathrm{C}$. Tritt eine Überwärmung bei einem Neugeborenen auf, so setzt eine Vasodilation und Schweißdrüsensekretion ein. Bei Umgebungstemperaturen zwischen $36^{\circ}$ und $38^{\circ} \mathrm{C}$ verdoppelt sich der Sauerstoffverbrauch. Ein besonderes Augenmerk ist auf die häufiger auftretenden Apnoeanfälle zu richten, besonders während der Erwärmungsphase.

Bei Kälteexposition des Neugeborenen setzt eine Vasokonstriktion ein, die allerdings in der Regel nicht ausreicht, dem gesamten Wärmeverlust entgegenzuwirken. So kann z. B. bei Umgebungstemperaturen von $23^{\circ} \mathrm{C}$ eine Steigerung des Stoffwechsels (Tab. II) und des Sauerstoffverbrauchs von über $100 \%$ beobachtet werden. Weiterhin kommt es zu einer Erhöhung des Katecholamins, der freien Fett- säuren und des Laktats sowie zur metabolischen Acidose (Tab. III). Es kann ein erhở hter, aber auch erniedrigter Blutzuckerspiegel gefunden werden. In den ersten Lebensstunden wird bei Kälteeinwirkung ein erhöhter Thyreotropingehalt gemessen. Die Diffusionskapazität des Bilirubins in das Gewebe ist bei unterkühlten Neugeborenen vergrößert, so daß eine größere Gefahr des Kernikterus besteht. Kinder nach einer Risikogeburt besitzen eine verzögert einsetzende Vasoreaktion und eine verminderte Wärmeproduktion, sie können besonders rasch auskühlen.

Bei 255 im 1. Halbjahr 1971 in der Kinderklinik der FU Berlin aufgenommenen unter 24 Stunden alten Neugeborenen betrug die durchschnittliche Aufnahmetemperatur $35,5^{\circ} \mathrm{C}$ (Tab. IV). Es bestand eine deutliche Temperaturabhängigkeit vom Geburtsgewicht und vom Lebensalter. Die Aufnahmetemperatur war unabhängig von der Enfernung der einweisenden Klinik (Tab. V) und von der Jahreszeit. Der entscheidende Temperaturverlust muß unmittel bar nach der Geburt stattfinden (Tab. VI). Es sollte darauf geachtet werden, daß Wärmelampen rechtzeitig eingeschaltet und richtig justiert werden. Nasse Tücher auf dem Wickeltisch müssen wegen des verstärkten Wärmeabstroms entfernt werden. Die Kinder sollten immer zugedeckt sein. Um einen kontinuierlichen Wärmeschutz von Geburt bis zur stationären Versorgung zu ermöglichẹn, sollten in den Kreißsälen mehr Wärmebettchen und Inkubatoren stehen, in denen die Neugeborenen auch reanimiert werden können.

Da bei der Anwendung der kontrollierten Hypothermie bei Neugeborenen zur Senkung des Sauerstoffverbrauchs noch zu wenig Erfahrungen vorliegen, erscheint ein ausreichender Wärmeschutz bei der Erstversorgung heute noch unerläßlich.

Schlüsselworte: Körpertemperatur (Regulation), Neugeborenen-Überwachung, Neugeborenen-Umweltbedingungen.

\section{Resumé}

Nécessité de la prophylaxie thermique chez les nouveaux-nés

Le refroidissement des nouveaux-nés aussitôt post partum peut être dû à une modification des facteurs d'environnement et à la constitution physique. Outre la couche adipeuse sous-cutanée mince, surtout chez les prématurés et les enfants avec hypotrophie néonatale ("small for date"), le rapport de surface-volume est de 3 à 4 fois supérieur à celui des adultes (Tab. I).

Le nouveau-né peut retenir jusqu'à un certain degré le reflux de chaleur permanent grâce à une régulation de température efficace. Les nouveaux-nés prématurés et à terme possèdent des réactions vasculaires positives et une bonne sécrétion sudoripare. $\mathrm{La}$ production thermique est maintenue par des processus métaboliques dans les tissus adipeux blancs et, surtout, bruns. Par suite de l'absence de myastasie, on parle de thermogénèse sans tremblement du nouveau-né.

La température neutre, $c$. à $d$. cette température ambiante où le métabolisme de base est le plus bas, se situe chez le nouveau-né à terme entre $32^{\circ}$ et $34^{\circ} \mathrm{C}$ pour une humidité de l'air de $50 \%$, et même au-dessus de $34^{\circ} \mathrm{C}$ chez les prématurés selon le poids à la naissance et l'âge. En cas d'hyperthermie chez un nouveau-né, on observe une vasodilatation et une sécrétion sudoripare. La consommation d'oxygène double pour des températures ambiantes situées entre $36^{\circ}$ et $38^{\circ} \mathrm{C}$. Il convient de faire spécialement attention aux crises fréquentes d' apnée, surtout durant la phase de réchauffement.

Une cryoexposition du nouveau-né provoque une vasoconstriction qui ne suffit généralement pas, toutefois, pour compenser toute la déperdition calorique. C'est ainsi, par 
exemple, que l'on peut observer pour des températures ambiantes de $23^{\circ} \mathrm{C}$ une hausse du métabolisme (Tab. II) et de la consommation d'oxygène de plus de 100\%. On constate en plus une augmentation de la catecholamine, des acides gras libres et du lactate ainsi qu'une acidose métabolique (Tab. III). Il peut se produire également un taux de glycémie élevé ou inférieur.

Dans les premières heures de la vie, on mesure en cas de refroidissement une teneur élevée en thyrostimuline. La capacité de diffusion de la bilirubine dans les tissus est plus grande chez les nouveaux-nés dont la température du corps est trop basse, de sorte qu'il existe un plus grand risque d'ictère nucléaire. Après une naissance difficile, on observe chez les enfants une réaction vasculaire retardée et une production thermique réduite, ce qui provoquer un refroidissement particulièrement rapide.

Chez 255 nouveaux-nés de moins de $24 \mathrm{~h}$ admis à l'Université Libre de Berlin durant le premier semestre 1971, la température moyenne à l'admission était de $35,5^{\circ} \mathrm{C}$ ( $\mathrm{Tab}$. IV). On a pu constater une corrélation très nette entre le degfré de température d'une part, et le poids à la naissance ainsi que l'âge d'autre part. Par contre, on n'a observé aucune corrélation entre la température à l'admission et l'éloignement de l'hôpital (Tab. V) ayant envoyé l'enfant ou la saison de l'année. Il est donc très probable que la baisse décisive de température se produit directement après la naissance (Tab. VI). En conséquence, il faut veiller à allumer en temps voulu et à régler correctement les lampes chauffantes. Il convient également d'éloigner tout linge humide de la table à langer à cause du reflux de chaleur accru. Veiller aussi à ce que les enfants soient toujours bien couverts. Il faudrait aussi prévoir dans les salles de traveil davantage de lits chauffants et d'incubateurs avec appareils de réanimation afin de pouvoir assurer une protection calorique continue de la naissance jusqu'à l'hospitalisation.

Les expériences étant encore insuffisantes sur l'utilisation de l'hypothermie contrôlée chez les nouveaux-nés pour faire baisser la consommation d'oxygène, il nous paraît encore indispensable aujourd'hui d'assurer une protection calorique suffisante dans les premiers soins.

Mots-clés: Régulation de la température du corps, environnement néonatal, les soins des nouveaux-nés.

\section{Bibliography}

[1] Adams, F. H., T. Fujtwara, R. Spears, J. Hodgman: Temperature regulation in premature infants. Pediatrics 33 (1964) 487

[2] Adamsons, K., Jr., G. M. Gandy, L. S. James: The influence of thermal factors upon oxygen consumption of the newborn human infant. J. Pediat. 66 (1965) 495

[3] Berg, K., O. Celander: Circulatory adaptation in the thermoregulation of fullterm and premature newborn infants. Acta Paediat. Scand. 60 (1971) 278

[4] Bleyl, U.: Pathomorphologie und Pathogenese des Atemnotsyndroms. Verh. Deutsch. Ges. Path. 55 (1971) 39

[5] BRUECK, K.: Temperature regulation in the newborn infant. Biol. Neonate 3 (1961) 65

[6] Brueck, K., M. Brueck, H. Lemtrs: Hautdurchblutung und Thermoregulation bei reifen und unreifen Neugeborenen. Arch. Gynäk. 190 (1958) 512

[7] Brueck, K., M. Brueck, H. Lemtis: Die Temperaturregelung Neugeborener und Frühgeborener nach spontaner und pathologischer Geburt. Geburtsh. Frauenheilk. 20 (1960) 461

[8] Brueck, K., A. H. Parmelee, Jr., M. Brueck: Neutral temperature range and range of "thermal comfort" in premature infants. Biol. Neonate 4 (1962) 32

[9] Brueck, K., B. Wuennenberg: Blockade., der chemischen Thermogenese und Auslösung vori Muskelzittern durch Adrenolytica und Ganglienblockade beim neugeborenen Meerschweinchen. Pfluegers Arch. 282 (1965) 376

[10] BuETOW, K. C., S. W. KLEIN: Effect of maintenance of "normal" skin temperature on survival of infants of low birth weight. Pediatrics 34 (1964) 163
[11] Dahm, L. S., L. S. James: Newborn temperature and calculated heat loss in the delivery room. Pediatrics 49 (1972) 504

[12] Daily, W. J. R., M. Klaus, H. B. P. Meyer: Apnea in premature infants: Monitoring, incidence, heart rate changes, and an effect of environmental temperature. Pediatrics 43 (1969) 510

[13] Dawkins, M. J. R., D. HuLl: The production of heat by fat. Sci. Amer. 213 (1965) 62

[14] DAY, R.: Respiratory metabolism in infancy and in childhood. Amer. J. Dis. Child. 65 (1943) 376

[15] Day, R. L., L. Caliguiri, C. Kamenski, F. Ehrlich: Body temperature and survival of premature infants. Pediatrics 34 (1964) 171

[16] DunN, J. M., J. A. Mrller, Jr.: Hypothermia combined with positive pressure ventilation in resuscitation on the asphyxiated neonate. Amer. J. Obstet. Gynec. 104 (1969) 58

[17] Fekete, M., R. D. G. Milner, Gy. Soltész, R. Assan, J. Mestyán: Plasma glucagon, thyrotropin, growth hormone and insulin response to cold exposure in the human newborn. Acta Paediat. Scand. 61 (1972) 435

[18] Fisher, D. A., T. H. Oddie, E. J. Makoski: The influence of environmental temperature on thyroid, adrenal, and water metabolism in the newborn human infant. Pediatrics 37 (1966) 583

[19] Gandy, G. M., K. Adamsons, Jr., N. Cunningham, W. A. Silverman, L. S. James: Thermal environment and acid-base homeostasis in human infants during the first few hours of life. J. Clin. Invest. 43 (1964) 751

[20] Glass, L., W. A. Silverman, J. C. Sinclair: Effect 
of the thermal environment on cold resistance and growth of small infants after the first week of life. Pediatrics 41 (1968) 1033

[21] Glerss, J.: Beiträge zum Frühgeburtenproblem der Gegenwart. 3. Mitteilung: Die iatrogene Komponente des Kältetodes der Frühgeburt. Z. Kinderheilk. 73 (1953) 146

[22] GLEIss, J.: Über einige Mängel der initialen Frühgeborenen-Betreuung. Mschr. Kinderheilk. 116 (1968) 269

[23] Heim, T., D. Hull: The effect of propranalol on the calorigenic response in brown adipose tissue of newborn rabbits to catecholamines, glucagon, corticotrophin and cold exposure. J. Physiol. 187 (1966) 271

[24] Hensel, H.: Temperaturregulation. In: KeIDEL, W. D.: Kurzgefaßtes Lehrbuch der Physiologie. Thieme, Stuttgart 1967

[25] Hex, E. N.: The relation between environmental temperature and oxygen consumption in the newborn baby. J. Physiol. 200 (1969) 589

[26] Hey, E. N., G. Katz: Evaporative water loss in the newborn baby. J. Physiol. 200 (1969) 605

[27] Hey, E. N., G. Katz: The optimum thermal environment for naked babies. Arch. Dis. Child. 45 (1970) 328

[28] Hsieh, A. C. L., L. D. Carlson: Role of adrenaline and noradrenaline in chemical regulation of heat production. Amer. J. Physiol. 190 (1957) 243

[29] Hull, D.: The structure and function of brown adipose tissue. Brit. Med. Bull. 22 (1966) 92

[30] Hull, D., M. M. Segall: Sympathetic nervous control of brown adipose tissue and heat production in the new-born rabbit. J. Physiol. 181 (1965) 458

[31] JochmanN, M.: Über den Einfluß der Unterkühlung auf die Lebenserwartung der Frühgeborenen. Berl. Med. (1969) 272

[32] MaNN, T. P.: Observations on temperatures of mothers and babies in the perinatal period. J. Obstet. Gynaec. Brit. Cwlth. 75 (1968) 316

[33] Mersmann, B., H. Haupt: Untersuchungen zur Frage der Frühgeborenenunterkühlung. I. Mitteilung. Häufigkeit und Bedeutung der accidentellen Unterkühlung. Mschr. Kinderheilk. 119 (1971) 450

[34] MersmanN, B., H. Haupt: Untersuchungen zur Frage der Frühgeborenenunterkühlung. II. Mitteilung. Warum kommen Frühgeborene unterkühlt ins Frühgeborenenzentrum? Mschr. Kinderheilk. 119 (1971) 455

[35] MersmanN, B., H. Haupt: Untersuchungen zur Frage der Frühgeborenenunterkühlung. III. Mitteilung. Temperaturverhältnisse während des Frühgeborenentransportes im Transportinkubator. Mschr. Kinderheilk. 119 (1971) 458

[36] Mrller, J. A., Jr.: New approaches to preventing brain damage during asphyxia. Amer. J. Obstet. Gynec. 110 (1971) 1125
[37] Miller, J. A., Jr.: Personal communication, 1972

[38] Novik, M., V. Melichar: Die Veränderung der Fettsäureutilisation im subkutanen Fettgewebe des Neugeborenen. In: Jopprch, G., H. Wolf: Stoffwechsel des Neugeborenen, Hippokrates, Stuttgart 1970

[39] Perlstein, P. H., N. K. Edwards, J. M. SutherLAND: Apnea in premature infants and incubatorair-temperature changes. New Eng. J. Med. 282 (1970) 461

[40] Persson, B., R. Tunell: Influence of environmental temperature and acidosis on lipid mobilization in the human infant during the first two hours after birth. Acta Paediat. Scand. 60 (1971) 385

[41] ReIN, H., M. Schneider: Physiologie des Menschen, 13./14. Auflage, Springer, Berlin-Göttingen-Heidelberg 1960

[42] Schiff, D., L. Stern, J. Leduc: Chemical thermogenesis in newborn infants: Catecholamine excretion and the plasma non-esterified fatty acid response to cold exposure. Pediatrics 37 (1966) 577

[43] SEMM, K., D. KRESS: Fahrbare Reanimationseinheit für Neugeborene. Geburtsh. Frauenheilk. 31 (1971) 964

[44] Silverman, W. A., J. W. Fertig, A. P. Berger: The influence of the thermal environment upon the survival of newly born premature infants. Pediatrics 22 (1958) 876

[4! .jnclair, J. C.: Heat production and thermoregulation in the small-for-date infant. Pediat. Clin. N. Amer. 17 (1970) 147

[46] Smrth, R. E., B. A. Horwriz: Brown fat and thermogenesis. Physiol. Rev. 49 (1969) 330

[47] StERN, L.: Temperature Control, Hydration and Feeding, Bilirubin and Calcium Metabolism. Biol. Neonate 16 (1970) 92

[48] Stern, L., M. H. Lees, J. Leduc: Environmental temperature, oxygen consumtion, and catecholamine excretion in newborn infants. Pediatrics 36 (1965) 367

[49] Taehti, E., J. Lind, K. Oesterlund, E. RYlander: Changes in skin temperature of the neonate at birth. Acta Paediat. Scand. 61 (1972) 159

[50] Westin, B.: Hypothermia. In: HuntingFord, P. J., K. A. Hüter, E. SalING: Perinatal Medicine. 1. European Congress of Perinatal Medicine, Berlin 1968. Thieme, Stuttgart 1969

[51] Westin, B., J. A. Miller, Jr., A. Boles: Hypothermia induced during asphyxiation. Its effects on survival rate, learning and maintenance of the conditioned response in rats. Acta Paediat. Scand. 52 (1963) 49

[52] Wolf, H., U. Stave: Postnatale Thermoregulation und Fettstoffwechsel. In: Wresener, H.: Inteñsivpflege bei Neugeborenen. Thieme, Stuttgart 1971

Dr. H. Schachinger

Kaiserin Auguste Victoria Haus

Universitäts-Kinderklinik

Heubnerw̄eg 6

D-1000 Berlin 19/Germany 